\title{
UMBATRA
}

Indonesian Journal of Anthropology

Volume 3 (1) Juli 2018 || eISSN 2528-1569 | pISSN 2528-2115 || http://jurnal.unpad.ac.id/umbara

DOI : 10.24198/umbara.v3i1.25576

\section{Peran Perempuan dalam Keluarga Petani Pegunungan Tengger}

\author{
Maria Novita Sitanggang \\ Program Studi Antropologi, FISIP, Universitas Padjadjaran \\ marianovitas656@gmail.com
}

\begin{abstract}
Women play double roles in the society, in the public sphere as worker who earn income for the household, and in the domestic sphere as housewives. This research discusses women's roles in peasant family. This research applies qualitative method. Data collection technique includes participant observation, in-depth interview, and archival study. Data were analysed using AGIL's theory of social change (Adaptation, Goal, Integration, Latency) by Talcott Parson; and Harvard-Moser gender analytical frameworks. This study suggests that women in peasant family have multiple roles; as a spouse and housewives in domestic sphere, and as farmer and as member of the community in public sphere. Women take responsibility in educating children in the domestic sphere; while in the public sphere, as farmer, they contribute significantly to their family income.
\end{abstract}

Keywords:Women, roles, farmer, family, AGIL, Harvard and Moser's gender analysis

\begin{abstract}
Abstrak
Perempuan seringkali harus memainkan dua peran sekaligus; di ranah publik sebagai pekerja untuk memenuhi kebutuhan keluarga, dan di ranah domestik sebagai ibu rumah tangga. Penelitian ini bertujuan menggambarkan ragam peran yang dilakoni perempuan dengan menampilkan kasus perempuan di dalam keluarga petani. Penelitian ini menggunakan metode kualitatif. Sampel dipilih secara purposive. Teknik pengumpulan data dilakukan melalui pengamatan terlibat, wawancara mendalam, dan data sekunder. Hasil penelitian dianalisis mengikuti prinsip analisis data kualitatif. Teori perubahan sosial AGIL (Adaptation, Goal, Integration. Latency) yang digagas oleh Talcott Parson dan teknik analisis gender Harvard dan Moser yang digunakan sebagai kerangka untuk menganalisis peran perempuan. Hasil penelitian menunjukkan bahwa peran perempuan di dalam masyarakat dan keluarga sangat beragam dan penting yaitu sebagai ibu rumah tangga, sebagai petani sebagai anggota masyarakat. Perempuan juga merupakan aktor yang turut menopang ekonomi keluarga, sebagai aktor yang bertugas mencurahkan afeksi pada anak, serta aktor yang bertanggung jawab dalam proses sosialisasi dan pendidikan anak di dalam keluarga.
\end{abstract}

Kata kunci: Perempuan, peran, petani, keluarga, AGIL, dan analisis gender Harvard Moser 


\section{Pendahuluan}

Keluarga adalah kumpulan individu yang hidup dalam satu rumah tangga dan terikat oleh pertalian darah, ikatan perkawinan, atau adopsi (pengangkatan). Di dalam rumah tangga, anggota keluarga saling berinteraksi dan menjalankan perannya masing-masing menurut nilai dan norma kebudayaan setempat (Bailon dan Maglaya, 1989 dalam Hartono, et al., 2009). Keluarga memiliki beberapa fungsi di masyarakat, yaitu: 1) fungsi sosialisasi 2) fungsi pendidikan dan 3) fungsi afeksi. Fungsi sosialisasi merujuk pada keluarga sebagai tempat pembelajaran interaksi pada anak. Fungsi pendidikan merujuk pada keluarga sebagai tempat pendorong individu mempelajari aneka hal yang berkaitan dengan pendidikan untuk mempersiapkan anak menjadi anggota masyarakat yang baik. Fungsi afeksi merujuk pada keluarga sebagai tempat penyedia kasih sayang bagi anggotanya (Silalahi dan Eko, 2010).

Di dalam keluarga terjadi proses sosialisasi mengenai aneka hal, salah satunya sosialisasi mengenai peran gender. Gender adalah perbedaan karakteristik, peran, fungsi, hak, tanggung jawab, dan perilaku antara laki-laki dan perempuan yang dibentuk oleh nilai sosial, budaya, dan adat istiadat masyarakat. Konsep gender bersifat dinamis, berubah dan beragam menurut waktu serta setting budaya (Fakih, 2008 dalam Puspitawati, 2013). Sosialisasi mengenai peran gender di dalam keluarga biasanya berisi penanaman pengetahuan tentang perbedaan peran sesuai dengan karakter, yaitu feminin dan maskulin (Mackie, 1991 dalam Warmiyati, et al., 2018).

Pembagian peran gender bagi laki-laki dan perempuan di Indonesia sebagian besar masih mengikuti ideologi gender klasik, laki-laki di sektor publik dan perempuan di sektor domestik. Namun, seiring perubahan sosial, peran ini mulai dipertukarkan. Perempuan mulai turut memasuki sektor publik untuk bekerja memenuhi kebutuhan ekonomi keluarganya (Triana dan Kristiani, 2018). Gejala partisipasi perempuan di sektor publik telah mulai sejak emansipasi perempuan diperjuangkan oleh Raden Ajeng Kartini. Kini perempuan di Indonesia pun memiliki kesempatan untuk melakukan kegiatan di sektor publik, seperti bekerja, yang biasanya didominasi oleh laki-laki.

Perempuan adalah obyek studi yang kompleks dan menarik untuk dikaji dengan perspektif gender. Kajian gender pada perempuan seringkali menyoroti isu mengenai peran gender terutama peran perempuan di masyarakat. Di dalam kajian mengenai peran gender, perempuan selalu erat dengan peran domestik yaitu peran di wilayah rumah tangga. Di dalam rumah tangga, peran perempuan sangatlah penting yaitu sebagai istri, yang dituntut untuk bijak serta menjadi mitra suaminya dalam mengurus rumah tangga dan sebagai ibu yang mengurus anak-anaknya (Triana dan Kristiani, 2018). Selain peran domestik, perempuan juga memiliki peran dalam ranah publik, yaitu perempuan berperan dalam membantu perekonomian rumah tangga dengan menjadi seorang pekerja (Sukesi, 1991).

Seringkali, perempuan mengalami konflik akibat multi peran yang dilakoninya. Konflik peran biasanya dialami perempuan urusan pekerjaan (publik) bertemu urusan berkeluarga (domestik). Perempuan pekerja seringkali dituntut mengurangi waktu yang dihabiskan dalam pekerjaan dan menyediakan lebih banyak waktu untuk keluarga (Forrest, et al., 1975 dalam Akbar, 2017). Penelitian Rahayuningsih (2013) menemukan bahwa 33 persen perempuan mengalami konflik peran. Pada kasus konflik peran, perempuan memerlukan dukungan keluarga maupun masyarakat luas untuk mengatasinya. Kaufmann dan Beehr (1989) dalam Apollo dan Cahyadi (2013) menjelaskan bahwa perempuan memerlukan dukungan sosial dari keluarga untuk mengatasi masalah konflik peran tersebut.

Penelitian ini bertujuan mendeskripsikan peran perempuan yang beragam dan jamak dengan menampilkan contoh kasus perempuan dalam keluarga petani di pegunungan Tengger. Pada 
keluarga petani, perempuan menjalankan peran dalam dua ranah sekaligus, yaitu domestik (rumah tangga) sebagai ibu bagi anaknya serta istri dan mitra bagi suami, dan di ranah publik, perempuan bekerja sebagai petani di ladang.

Penelitian ini menggunakan teori Parson tentang Tahapan Perubahan Sosial AGIL (Adaptation, Goal, Attainment, Integration, dan Latency) sebagai kerangka analisis (Parson, 1946 dalam Wirawan, 2012). Teori ini digunakan untuk menjelaskan tahapan perempuan dalam beradaptasi dengan perannya di masyarakat. Selain teori AGIL, penelitian ini juga memetakan peran perempuan dalam keluarga dengan metode analisis gender Harvard dan Moser untuk memetakan pembagian peran gender di dalam keluarga, terutama pembagian waktu antara laki-laki dan perempuan.

\section{Kajian Pustaka}

Tingkat sosial ekonomi keluarga yang rendah mendorong perempuan dari kelas bawah turut memasuki sektor publik untuk bekerja menambah penghasilan keluarga dan meningkatkan kemandirian ekonomi. Beberapa penelitian menyebutkan mengenai partisipasi perempuan dalam sektor kerja serta dampaknya. Perempuan pemetik teh turut bekerja untuk membantu suami mereka mencari nafkah. Profesi sebagai pemetik teh membantu perempuan menjadi lebih mandiri secara ekonomi dan memiliki peran dalam pengambilan keputusan di keluarga meski pekerjaan mereka itu berupah rendah dan tidak meningkatkan kesejahteraan secara signifikan (Kusumawati, 2012). Perempuan buruh tani di Magelang Jawa Tengah, melakoni multi peran karena dorongan kebutuhan ekonomi dan rendahnya pendidikan serta keterampilan yang mereka miliki (Dewi dan Lestari, 2017).

Keterlibatan perempuan dalam dua ranah sekaligus menempatkan mereka sebagai ibu rumah tangga dan sebagai pencari nafkah sekaligus. Seringkali, perempuan menghadapi dilema karena mereka diharuskan melakoni peran itu pada saat yang bersamaan. Di satu sisi, sebagai aktor rumah tangga mereka harus siap sedia kapan saja di rumah, sedang- kan di sisi lain mereka sebagai pekerja terikat pada jam kerja yang mengharuskan mereka berada di tempat kerja dan meningkatkan etos kerja (Rahmaharyati, Wibhawa, dan Nurwati, 2017). Selain persoalan pengaturan waktu, keterlibatan perempuan untuk bekerja juga menimbulkan persoalan tambahan, yaitu beban perempuan. Di tempat kerja, perempuan dihadapkan pada tuntutan pekerjaan demi pemenuhan fungsi kebutuhan ekonomi keluarga, sedangkan ketika sudah berada di rumah, perempuan masih dihadapkan pada peran domestik yaitu pemenuhan fungsi kebutuhan keluarga. Di dalam menjalankan peran tersebut, perempuan memerlukan keterampilan cukup dan dukungan sosial dari suami dan anak-anaknya untuk menghindari terjadinya konflik yang menyulitkan. Perempuan yang memiliki keterampilan membagi waktu dan dukungan sosial tinggi cenderung lebih mampu memenuhi peran dan mengatasi implikasi negatif dibanding perempuan yang condong pada salah satu peran saja dan kurang memperoleh dukungan sosial.

Greenhaus dan Beutell (1985) dalam Ramadhani (2016) memaparkan tiga macam konflik peran ganda yang sering dialami perempuan di antaranya: 1) time-based conflict yaitu waktu yang dibutuhkan untuk menjalankan salah satu tuntutan yang lainnya (pekerjaan atau keluarga), 2) strain-based conflict yaitu tekanan dari salah satu peran yang memengaruhi kinerja peran lainnya, dan 3) behavior-based conflict yang berhubungan dengan ketidaksesuaian antara pola perilaku dengan yang diinginkan oleh kedua bagian (pekerjaan atau keluarga).

Dukungan sosial adalah aneka bentuk tindakan yang bersifat membantu dalam melibatkan emosi, pemberian informasi, dan penilaian positif pada individu dalam menghadapi permasalahan (Cohen dan Syme, 1985 dalam Apollo dan Cahyadi, 2013; House dan Khan, 1985 dalam Indriani dan Sugiasih, 2018; Robert dan Greene, 2009 dalam Pramana dandan Wilani, 2018). Sumber-sumber dukungan sosial adalah orangtua, saudara kandung, anak-anak, kerabat, pasangan hidup, sahabat rekan sekerja, dan tetangga sekitarnya (Apollo dan Cahyadi, 2013). 
Lebih lanjut, Robert dan Greene (2009) dalam Pramana dandan Wilani (2018) menyebut bahwa dukungan sosial meliputi dukungan emosional, dukungan informasional, dan dukungan konkret. Dukungan emosional berupa kesediaan menyimak dan mendengarkan perasaan seseorang guna memberikan motivasi serta kesan positif. Dukungan informasional berupa pemberian informasi untuk menyelesaikan masalah atau mengambil keputusan. Dukungan konkret berupa pemberian bantuan dalam bentuk barang atau tindakan.

Anggriana, Margawati, dan Wardani (2016) menunjukkan pengaruh signifikan dari dukungan sosial keluarga terhadap konflik peran ganda perempuan dalam keluarga. Semakin tinggi dukungan sosial keluarga maka semakin rendah konflik peran ganda, dan sebaliknya semakin rendah dukungan sosial keluarga maka semakin tinggi konflik peran ganda. Wibowo (2011) juga menyatakan bahwa persoalan peran ganda perempuan terjadi karena sektor domestik dan publik dilihat sebagai dua sisi yang terpisah secara diametral. Padahal jika itu dipandang sebagai dua titik yang terhubung secara kontinum, tentu dikotomi tidak akan muncul. Hal yang terpenting bagi laki-laki dan dan perempuan bukan untuk mengetahui di mana ia harus paling banyak menghabiskan waktu dan konsentrasinya, tetapi sejauh mana keduanya mempunyai pengabdian yang tinggi bagi rumah dan memperluas pengabdian melampaui fisik rumah.

Parson (1946) dalam Wirawan (2012) menyatakan tahapan dalam perubahan sosial untuk melihat strategi yang dilakukan oleh para perempuan dalam upaya menjalankan peran mereka yang beragam melalui AGIL (Adaption, Goal, Attainment, Integration, dan Latency) sebagai sebuah proses di mana individu berupaya untuk menjalani peran sosialnya. Teori ini menjelaskan bahwa demi keberlangsungan hidup manusia yang seimbang, maka masyarakat harus menjalankan fungsi-fungsi tersebut.

Konsep adaptation (adaptasi) merujuk pada kemampuan individu yang menyesuaikan dirinya dengan lingkungan dan bertahan di da- lam lingkungan itu. Attainment Goal (pencapaian tujuan) adalah konsep yang merujuk pada sebuah sistem yang menentukan cara mencapai tujuan. Konsep integration (integrasi) merujuk pada pengaturan hubungan antar komponen-komponen agar dapat berfungsi secara efektif dan maksimal. Perempuan menjalankan konsep integrasi dengan cara mengatur keselarasan perannya dengan nilai dan norma yang telah terstruktur sehingga ia dapat berfungsi dengan baik. Konsep latency atau pemeliharaan merupakan tahapan akhir dari proses perubahan sosial. Hal ini merujuk pada pola-pola yang sudah ada di masyarakat yang harus terus dipertahankan, diperbaiki, dan diperbaharui; misal motivasi individu-individu maupun pola-pola budaya yang menciptakan dan mempertahankan motivasi tersebut.

Kerangka analisis gender Harvard dikenalkan oleh Overholt, et al. (1984) dalam Puspitawati (2013). Metode ini bertujuan memetakan tugas perempuan dan laki-laki untuk melihat perbedaan tugas dan aktornya pada tiga peran utama. Tiga peran utama itu mencakup peran publik dengan kegiatan produktifnya, peran domestik dengan kegiatan reproduktifnya, dan peran kemasyarakatan dengan kegiatan sosial budayanya (Puspitawati, 2013). Ketiga peran ini digambarkan melalui pemetaan aktivitas yang melibatkan laki-laki dan perempuan dalam rumah tangga selama periode 24 jam. Analisis pola pembagian kerja berdasarkan profil kegiatan dan waktu dipetakan menggunakan metode analisis gender Moser (Puspitawati, 2013). Kedua metode ini digunakan dalam penelitian ini untuk menggambarkan peta peran dan alokasi waktu untuk menjalankan peran gender dalam keluarga petani.

\section{Metode}

Penelitian ini menggunakan metode penelitian kualitatif untuk menyelidiki dan menggambarkan dinamika multi peran perempuan dalam keluarga petani. Penelitian ini dilakukan di Desa Wonotoro dan Desa Ngadisari, Kecamatan Sukapura, Kabupaten Probolinggo, Provinsi Jawa Timur. Kedua desa ini terletak di dataran tinggi Bromo. 
Data yang dikumpulkan dalam tulisan ini meliputi: 1) faktor-faktor yang mendorong multi peran perempuan, 2) pola pembagian waktu dan kegiatan perempuan di ranah domestik dan publik, 3) peran perempuan pada pemenuhan kebutuhan ekonomi keluarga, 4) peran perempuan pada pemenuhan afeksi anak, 5) peran perempuan pada pemenuhan sosialisasi dan pendidikan anak, 6) dinamika kehidupan multi peran perempuan dalam waktu 24 jam. Pengumpulan data pada penelitian ini menggunakan teknik pengamatan terlibat, wawancara mendalam, dan studi data sekunder. Data sekunder didapatkan dari studi pustaka atas artikel, jurnal, dan skripsi.

Pemilihan sampel dalam penelitian ini dilakukan dengan teknik purposive sampling; yaitu teknik mengambil sampel data sesuai dengan tujuan penelitian (Creswell, 2013). Kriteria informan antara lain: a) perempuan bersuami petani, memiliki anak, dan turut bekerja di ladang sebagai petani, b) perempuan bersuami, memiliki anak, dan profesi suaminya sebagai selain petani, dan c) perempuan yang menjadi single parent atau orang tua tunggal karena suaminya telah meninggal. Informan berjumlah tiga orang dan masing-masing informan mewakili setiap kriteria informan

Analisis data diawali dengan mengumpulkan semua data primer yang didapatkan dari pengamatan, wawancara, dan data sekunder yang berasal dari monografi desa dan laporan-laporan. Data primer diolah dan dikategorisasi untuk mendapatkan pola isu dan gejala di lokasi penelitian. Selanjutnya pola-pola ini diinterpretasi untuk menjawab pertanyaan penelitian.

\section{Hasil dan Pembahasan}

Desa Ngadisari dan Desa Wonotoro terletak di Kecamatan Sukapura, Kabupaten Probolinggo, Provinsi Jawa Timur. Kecamatan Sukapura memiliki luas $102.08 \mathrm{~km}^{2}$. Kecamatan ini terletak di kawasan kaki pegunungan Tengger sekitar 33 kilometer dari pusat Kabupaten Probolinggo. Jenis tanah di Kecamatan Sukapura adalah tanah mekanis yang banyak mengandung mineral yang berasal dari letu- san gunung berapi yang berupa pasir dan batu, lumpur bercampur dengan tanah liat yang berwarna kelabu kekuning-kuningan. Sifat tanah semacam ini memiliki tingkat kesuburan yang tinggi, sehingga sangat cocok untuk ditanami sayur-sayuran.

Selain itu, Kecamatan Sukapura merupakan wilayah yang dikenal dengan eko-wisatanya. Hal tersebut karena letak kecamatan ini merupakan jalur yang dilalui untuk menuju Taman Nasional Bromo Tengger Semeru, tidak jarang kesempatan ini dimanfaatkan oleh masyarakat desa untuk menunjang kebutuhan hidup.

\section{Faktor Pendorong Multi Peran Perempuan}

Perempuan di kedua lokasi penelitian ini mayoritas telah menikah pada umur 19-20 tahun. Perempuan di kedua desa tersebut cenderung menikah di usia muda dan kurang memiliki keinginan untuk merantau atau melanjutkan pendidikan. Mereka lebih memilih tinggal di tempat lahir mereka, menjadi istri, ibu rumah tangga, dan bekerja di ladang sebagai petani.

Bagi masyarakat di Desa Ngadisari dan Wonotoro, profesi sebagai petani adalah sebuah tradisi yang dipelihara dan diwariskan. Mereka meyakini bahwa petani bukanlah jenis pekerjaan yang rendah. Mereka bahkan mencintai peran sebagai petani karena dianggap sebagai pekerjaan yang mulia untuk mensyukuri kekayaan alam yang diberi oleh Tuhan Yang Maha Esa. Selain itu, menjadi petani juga menjadi sumber penghasilan sehari-hari.

Petani perempuan di kedua desa ini melakukan pekerjaan bertani sebagai wujud kesetiaan mereka pada suami. Mereka berpikir bahwa tanah yang telah diwariskan oleh keluarganya harus tetap diolah dan lestari. Oleh karena itu, kebanyakan perempuan yang telah menikah akan mengikuti suaminya untuk bertani. Bagi para perempuan, pekerjaan menjadi petani dianggap menyenangkan. Sebab, jika perempuan hanya menjadi ibu rumah tangga saja maka kehidupan mereka terasa sangat membosankan. Mereka juga beranggapan bahwa hidup seorang perempuan haruslah diimbangi dengan bekerja. Perempuan yang telah me- 
nikah dan hanya berdiam diri di rumah tanpa pergi ke ladang dianggap sebagai hal yang kurang baik. Pemikiran seperti inilah yang kemudian mendorong para perempuan memiliki lebih dari satu peran. Mereka menjadi istri, ibu, sekaligus petani.

\section{Peran Perempuan pada Pemenuhan Kebu- tuhan Ekonomi}

Kebutuhan dasar manusia adalah pangan, sandang, dan papan. Demi pemenuhan kebutuhan itu, suami, istri, dan anak membagi peran mereka di dalam keluarga. Perempuan atau istri berperan menyiapkan kebutuhan pangan dan sandang. Mereka memasak, mencuci pakaian, dan merapikan pakaian. Suami bertugas untuk memperbaiki rumah apabila terjadi kerusakan. Di ladang, pembagian kerja dibuat berdasarkan jenis kelamin. Mayoritas laki-laki bertugas mencangkul (gulitan), memberikan pupuk, memberikan obat pada tanaman, dan membuat bedengan. Perempuan bertugas menanam dan menyiangi tanaman, termasuk mencabut gulma, dan tanaman yang rusak.

Perempuan dan laki-laki bekerja secara bergantian. Laki-laki memulai pekerjaan tani dengan mempersiapkan lahan dan termasuk membuat bedengan. Kegiatan dilanjutkan oleh perempuan yaitu menanam. Laki-laki melanjutkan kegiatannya setelah proses tanam selesai, yaitu memupuk. Beberapa hari setelah pemupukan, laki-laki lanjut bekerja yaitu melakukan pengobatan pada tanaman.

Perempuan dan laki-laki memang telah memiliki masing-masing peran dalam pekerjaan di ladang, tetapi menurut penuturan warga setempat, baik laki-laki dan perempuan juga harus mampu melakukan seluruh jenis pekerjaan di ladang secara keseluruhan. Tujuannya agar laki-laki maupun perempuan dapat saling menggantikan pekerjaan ketika salah satu pihak tidak dapat mengerjakan tugasnya, misal karena sakit atau ada pekerjaan lain.

Ada kalanya para suami di kedua desa ini tidak dapat melakukan tugasnya di ladang karena ia mendapatkan panggilan pekerjaan lain. Laki-laki yang ada di Ngadisari dan Wonotoro kebanyakan memiliki pekerjaan selain bertani yaitu sebagai pengantar wisatawan (pemandu wisata).

\section{Peran Perempuan pada Pemenuhan Afeksi Anak}

Perempuan memiliki peran penting dalam pemenuhan kebutuhan afeksi anak. Pemenuhan perempuan pada peran ini terlihat dari intensitas dan kedekatan hubungan mereka dengan anak. Apabila suami sedang melakukan pekerjaan lain, biasanya anak membantu atau mengantarkan ibunya ke ladang. Apabila anak masih balita, petani perempuan menitipkan anaknya pada sanak keluarga. Apabila tidak ada saudara yang dititipi anak, perempuan membawa anaknya ikut ke ladang. Apabila anak telah dewasa, ia dapat memilih ikut membantu orang tua di ladang atau bekerja di tempat lain. Orang tua terutama ibu, tidak memberikan pembatasan berlebihan pada pilihan pekerjaan anaknya. Menurut mereka, pembatasan justru menimbulkan dampak kurang baik bagi hubungan orang tua dan anak.

Ibu Sudi, salah satu warga desa, menuturkan bahwa anaknya memiliki rasa empati yang tinggi pada orang tua. Ia menduga, hal itu muncul karena ia selalu mencurahkan kasih sayang dan perhatian pada anaknya sedari kecil. Ia tidak pernah memarahi anaknya. Sebab memarahi anak, menurutnya, justru akan membuat anak menjadi nakal. Oleh karena itu ia selalu memberikan perhatian dan kasih sayang pada anaknya.

Pemenuhan kasih sayang orang tua terhadap anaknya diberikan oleh orang tua sejak anak masih balita. Salah satu warga yang memiliki anak yang berusia lima tahun, selalu menjadwalkan rekreasi dengan anaknya setidaknya sekali setiap tahun. Tujuan rekreasi, selain untuk memanjakan anak, juga bertujuan memperkuat ikatan di antara anggota keluarga yang seringkali sulit dilakukan karena kesibukan mereka sehari-hari.

Perempuan di kedua desa tempat penelitian ini mengatakan bahwa hubungan anak dan ibu sangatlah dekat. Mereka biasa menghabiskan 
waktu bersama untuk menonton televisi atau berbincang-bincang atas kejadian-kejadian yang mereka alami. Kecanggihan teknologi saat ini tidak mengurangi intensitas kedekatan mereka, karena mereka jarang menggunakan gawai ketika sedang bersama-sama. Gawai hanya mereka gunakan sesekali ketika ingin menghubungi orang yang jaraknya relatif jauh.

\section{Peran Perempuan dalam Sosialisasi dan Pendidikan Anak}

Perempuan berperan dalam pemenuhan kebutuhan sosialisasi dan pendidikan anak. Ia mengajarkan kebiasaan interaksi yang baik dan memberikan dukungan pada anak untuk tekun menuntut ilmu. Seorang perempuan yang telah menjadi ibu mulai memberikan tatanan nilai dan norma anaknya sedari kecil, termasuk menasihati anak apabila melakukan tindakan yang kurang baik, mengajarkan nilai sopan santun anak pada orang lain terlebih pada orang yang lebih tua. Apabila anak akan bepergian ke luar rumah, ia harus meminta izin terlebih dahulu pada orang tua. Selain itu, anak tidak diizinkan pergi jauh dari rumah dan dalam waktu yang lama. Apabila anak mengalami masalah, maka ibu akan memberikan ruang dan waktu bagi anaknya untuk bercerita. Anak pun tidak segan untuk berbagi masalahnya pada ibu mereka. Mayoritas anakanak di desa ini selalu menyampaikan keluh kesah mereka pada ibu.

\section{Peta Multi Peran Perempuan dalam 24 Jam}

Berdasarkan analisis Harvard pada kegiatan perempuan dan laki-laki selama 24 jam di kedua desa, diperoleh gambaran bahwa perempuan memiliki jumlah kegiatan rumah tangga yang lebih banyak dibandingkan dengan laki-laki.

\section{a) Ibu Laras}

\begin{tabular}{lll}
\hline Kegiatan & $\begin{array}{l}\text { Perem- } \\
\text { puan }\end{array}$ & Laki-laki \\
\hline
\end{tabular}

\section{Produksi}

\begin{tabular}{lll}
\hline a. Pertanian & & \\
\hline $\begin{array}{l}\text { 1. Pembersihan lahan } \\
\text { (Mencangkul) }\end{array}$ & & $\mathrm{x}$ \\
\hline 2. Persiapan benih & $\mathrm{x}$ & \\
\hline 3. Penanaman & $\mathrm{x}$ & $\mathrm{x}$ \\
\hline $\begin{array}{l}\text { 4. Penyiangan/pem- } \\
\text { bersihan }\end{array}$ & $\mathrm{x}$ & \\
\hline 5. Pemupukan & & $\mathrm{x}$ \\
\hline $\begin{array}{l}\text { 6. Panen } \\
\text { 7. Pengeringan/ } \\
\text { penyimpanan }\end{array}$ & $\mathrm{x}$ & $\mathrm{x}$ \\
\hline $\begin{array}{l}\text { 8. Perawatan tana- } \\
\text { man/pemusnahan } \\
\text { hama atau penya- } \\
\text { kit }\end{array}$ & $\mathrm{x}$ & $\mathrm{x}$ \\
\hline
\end{tabular}

b. Pariwisata

1. Pengantar tamu $\mathrm{X}$ ke tempat wisata

\begin{tabular}{|c|c|c|}
\hline Reproduksi & & \\
\hline $\begin{array}{l}\text { 1. Membangunan } \\
\text { anak }\end{array}$ & $\mathrm{x}$ & \\
\hline $\begin{array}{l}\text { 2. Mengantar anak } \\
\text { ke sekolah }\end{array}$ & $\mathrm{x}$ & \\
\hline 3. Menjaga anak & $\mathrm{x}$ & \\
\hline $\begin{array}{l}\text { 4. Memasak dan } \\
\text { penyiapan } \\
\text { makanan }\end{array}$ & $\mathrm{x}$ & \\
\hline $\begin{array}{l}\text { 5. Intensitas kedeka- } \\
\text { tan dengan anak }\end{array}$ & $\mathrm{x}$ & \\
\hline $\begin{array}{l}\text { 6. Memberikan } \\
\text { ajaran nilai dan } \\
\text { norma pada anak }\end{array}$ & $\mathrm{x}$ & $\mathrm{x}$ \\
\hline $\begin{array}{l}\text { 7. Memberikan } \\
\text { dukungan pada } \\
\text { pendidikan anak }\end{array}$ & $\mathrm{x}$ & $\mathrm{x}$ \\
\hline
\end{tabular}

Sosial (Kemasyaraka-

$\tan )$

\begin{tabular}{lll}
\hline $\begin{array}{l}\text { 1. Interaksi dengan } \\
\text { tetangga }\end{array}$ & $\mathrm{x}$ & $\mathrm{x}$ \\
\hline
\end{tabular}

$\mathrm{Bu}$ Laras selalu bangun pada pukul 04.00 pagi dan memulai kegiatan mengurus rumah tangga; seperti membangunkan anak, menyiapkan sarapan, dan mencuci piring; serta mengantar dan menemani anaknya bersekolah. Pada pukul 10.00, setelah anaknya pulang sekolah, ia memulai pekerjaannya sebagai petani di 
ladang bersama suaminya. Biasanya ia bekerja di ladang hingga pukul 15.00. Berbeda dengan dirinya, suaminya lebih banyak menghabiskan waktu dengan bercengkerama dengan tetangga atau rekan kerjanya dibanding untuk bekerja.

Pada sore hari, rutinitas $\mathrm{Bu}$ Laras adalah menyiapkan makan malam. Selain itu, ia juga membantu pekerjaan rumah anaknya. $\mathrm{Bu}$ Laras biasanya berangkat tidur pada pukul 21.00. Setiap hari, ia masih menyempatkan waktu untuk berbincang-bincang dengan sesama pekerja petani perempuan di sela-sela rutinitasnya yang padat.

b) Ibu Sudi

\begin{tabular}{|c|c|c|}
\hline Kegiatan & $\begin{array}{l}\text { Perem- } \\
\text { puan }\end{array}$ & $\begin{array}{l}\text { Laki-la- } \\
\text { ki }\end{array}$ \\
\hline \multicolumn{3}{|l|}{ Produksi } \\
\hline \multicolumn{3}{|l|}{ a.Pertanian } \\
\hline $\begin{array}{l}\text { 1. Pembersihan lahan } \\
\text { (Mencangkul) }\end{array}$ & $\mathrm{x}$ & \\
\hline 2. Persiapan benih & $\mathrm{x}$ & \\
\hline 3. Penanaman & $\mathrm{x}$ & \\
\hline $\begin{array}{l}\text { 4. Penyiangan/pembersi- } \\
\text { han }\end{array}$ & $\mathrm{x}$ & \\
\hline 5. Pemupukan & $\mathrm{x}$ & \\
\hline 6. Panen & $\mathrm{x}$ & \\
\hline $\begin{array}{l}\text { 7. Pengeringan/penyim- } \\
\text { panan }\end{array}$ & $\mathrm{x}$ & \\
\hline $\begin{array}{l}\text { 8. Perawatan Tanaman/ } \\
\text { pemusnahan hama atau } \\
\text { penyakit }\end{array}$ & $\mathrm{x}$ & \\
\hline \multicolumn{3}{|l|}{ b. Pariwisata } \\
\hline $\begin{array}{l}\text { 1. Pengantar tamu ke } \\
\text { tempat wisata }\end{array}$ & & $\mathrm{x}$ \\
\hline \multicolumn{3}{|l|}{ Reproduksi } \\
\hline 1. Membangunan anak & $\mathrm{x}$ & \\
\hline $\begin{array}{l}\text { 2. Mengantar anak ke } \\
\text { sekolah }\end{array}$ & $\mathrm{x}$ & \\
\hline 3. Menjaga anak & $\mathrm{x}$ & \\
\hline $\begin{array}{l}\text { 4. Memasak dan penyia- } \\
\text { pan makanan }\end{array}$ & $\mathrm{x}$ & \\
\hline $\begin{array}{l}\text { 5. Intensitas kedekatan } \\
\text { dengan anak }\end{array}$ & $\mathrm{x}$ & \\
\hline
\end{tabular}

\begin{tabular}{llc}
\hline $\begin{array}{l}\text { 6. Memberikan ajaran } \\
\text { nilai dan norma pada } \\
\text { anak }\end{array}$ & $\mathrm{x}$ & $\mathrm{x}$ \\
\hline $\begin{array}{l}\text { 7. Memberikan dukungan } \\
\text { pada pendidikan anak }\end{array}$ & $\mathrm{x}$ & $\mathrm{x}$ \\
\hline Sosial (Kemasyarakatan) & & \\
\hline $\begin{array}{l}\text { 1. Interaksi dengan } \\
\text { tetangga }\end{array}$ & $\mathrm{x}$ & $\mathrm{x}$ \\
\hline
\end{tabular}

Bu Sudi melakukan pekerjaan bertani seorang diri. Hanya sesekali saja suaminya membantu. Ia lebih banyak dibantu oleh tetangga atau sanak keluarga yang bekerja di lahan yang dimilikinya. Bu Sudi memulai kegiatannya pada pukul 03.00 pagi. Kegiatan pertama yang ia lakukan setelah bangun tidur adalah mencuci pakaian, membangunkan anaknya, menyiapkan sarapan, dan menyapu rumah. Pada pukul 08.00, ia pergi ke ladang untuk bekerja hingga pukul 16.00. Pekerjaan utama suami Bu Sudi adalah bekerja di sektor wisata. Pada pukul 06.00, suaminya mengantar wisatawan berkeliling. Apabila tidak ada panggilan mengantar tamu, barulah suami Bu Sudi turut bekerja di ladang, tetapi hanya sampai pukul 12.00 siang saja. Setelah pukul 12.00 siang, biasanya suami Bu Sudi menghabiskan waktunya untuk bercengkerama dengan rekan kerja atau tetangganya. Sepulang dari ladang, Bu Sudi menyiapkan makan malam dan merapikan pakaian, dan bercengkerama dengan tetangga dan keluarganya. Pada pukul 21.00, ia beristirahat, disusul oleh anaknya dan suaminya pada pukul 23.00.

c) Ibu Sri

\begin{tabular}{llc}
\hline Kegiatan & $\begin{array}{l}\text { Perem- } \\
\text { puan }\end{array}$ & Laki-laki \\
\hline Produksi & & \\
\hline a.Pertanian & & \\
\hline $\begin{array}{l}\text { 1. Pembersihan lahan } \\
\text { (Mencangkul) }\end{array}$ & $\mathrm{x}$ & $\mathrm{x}$ \\
\hline 2. Persiapan benih & $\mathrm{x}$ \\
\hline 3. Penanaman & $\mathrm{x}$ \\
\hline 4. Penyiangan/pem- \\
bersihan
\end{tabular}




\begin{tabular}{ll}
\hline $\begin{array}{l}\text { 7. Pengeringan/penyim- } \\
\text { panan }\end{array}$ & $\mathrm{x}$ \\
\hline $\begin{array}{l}\text { 8. Perawatan tanaman/ } \\
\text { pemusnahan hama } \\
\text { atau penyakit }\end{array}$ & $\mathrm{x}$ \\
\hline b.Pariwisata & \\
\hline $\begin{array}{l}\text { 1. Pengantar tamu ke } \\
\text { tempat wisata }\end{array}$ & \\
\hline Reproduksi & $\mathrm{x}$ \\
\hline 1. Membangunkan anak & $\mathrm{x}$ \\
\hline \begin{tabular}{l} 
2. $\begin{array}{l}\text { Mengantar anak ke } \\
\text { sekolah }\end{array}$ \\
\hline 3. Menjaga anak
\end{tabular} & $\mathrm{x}$ \\
\hline \begin{tabular}{l} 
4. $\begin{array}{l}\text { Memasak dan } \\
\text { menyiapkan } \\
\text { makanan }\end{array}$ \\
\hline $\begin{array}{l}\text { 5. Intensitas kedekatan } \\
\text { dengan anak }\end{array}$
\end{tabular} \\
\hline $\begin{array}{l}\text { 6. Memberikan ajaran } \\
\text { nilai dan norma pada } \\
\text { anak }\end{array}$ \\
\hline $\begin{array}{l}\text { 7. Memberikan dukungan } \\
\text { pada pendidikan anak }\end{array}$ & $\mathrm{x}$ \\
\hline Sosial (Kemasyarakatan) \\
\hline $\begin{array}{l}\text { 1. Interaksi dengan } \\
\text { tetangga }\end{array}$ \\
\hline
\end{tabular}

Bu Sri adalah seorang single parent. Ia tinggal bersama anak laki-laki satu-satunya yang masih bersekolah di tingkat Sekolah Menengah Kejuruan (SMK). Sebelum Bu Sri mulai bekerja, ia memiliki tanggung jawab untuk mengurusi rumah dan anaknya terlebih dahulu. Bu Sri memulai aktivitas pada pukul 05.00 pagi. Ia membangunkan anaknya untuk bersiap-siap sekolah, Bu Sri membereskan pekerjaan rumah seperti mencuci pakaian dan menyapu rumah setelah anaknya berangkat sekolah sebelum pukul 07.00 pagi.

Pada pukul 07.00 hingga pukul 16.00, Bu Sri bekerja di ladang. Anak Bu Sri bersekolah mulai pukul 07.00 hingga 15.00. Sepulang sekolah, anak Bu Sri menjemput ibunya di ladang. Pada hari libur, anak Bu Sri bekerja sebagai pengantar tamu menggunakan kuda ke puncak Gunung Bromo. Sepulang dari ladang, Bu Sri memasak makan malam. Ia biasanya berbincang sebentar dengan anaknya setelah makan malam, dan pada pukul 21.00, mereka pun tidur.

\section{Dukungan Sosial Keluarga pada Perem- puan}

Tiga peran yang dimiliki perempuan di lokasi penelitian yaitu sebagai petani, ibu rumah tangga, dan anggota masyarakat. Para perempuan di sana menjalankan tiga peran sekaligus dan tidak mengalami konflik peran. Hal ini karena perempuan mendapatkan dukungan sosial yang cukup dari keluarga maupun orang di sekitarnya yaitu sesama pekerja petani maupun tetangga rumahnya. Sumber dukungan sosial yang paling berpengaruh pada para perempuan di lokasi penelitian adalah pasangan hidup dan anaknya. Fenomena ini sesuai dengan pendapat Robert dan Greene (2009) dalam Pramana dandan Wilani (2018) yang menjelaskan dukungan sosial meliputi tiga bentuk di antaranya dukungan emosional, dukungan informasional, dan dukungan konkret. Setiap kali perempuan pulang dari ladang, ia bersama keluarganya memanfaatkan waktu beristirahat untuk berbincang-bincang mengenai kegiatan mereka masing-masing sambil makan malam bersama. Para perempuan ini juga menganggap anak sebagai salah satu hiburan mereka ketika rasa lelah mulai dirasakan.

Dukungan informasional pun dirasakan oleh perempuan di lokasi penelitian. Ketika perempuan mempunyai masalah, maka ia selalu membicarakan masalah ini dengan keluarga terutama dengan pasangannya. Masalah yang dialami oleh perempuan biasanya mengenai pekerjaan di ladang, dan mengenai anak anaknya. Begitu pula dengan dukungan konkret. Perempuan memiliki peran yang jamak dalam keluarga. Seringkali, perempuan kehabisan energi dan kelelahan, terutama perempuan petani yang telah berusia di atas 40 tahun, tenaga mereka telah berkurang. Saat anak-anak mereka tumbuh dewasa, anak-anak itu memahami dan mendukung multi peran yang dimiliki ibunya. Sesekali anak-anak itu membantu ibu dan ayah mereka mengerjakan pekerjaan di ladang dan saat di rumah, anak-anak tersebut membantu pekerjaan rumah ibunya.

Para perempuan yang menjadi orang tua 
tunggal (single parent) memiliki pengalaman tersendiri. Mereka menganggap bahwa anak berperan memberikan dukungan setelah suami tiada. Anak memberikan dukungan baik emosional, informasional, dan dukungan konkret. Melalui kecukupan dukungan sosial ini, perempuan di lokasi penelitian sama sekali tidak mengalami konflik akibat multi peran itu.

\section{Multi Peran Perempuan}

Para perempuan petani di Desa Ngadisari dan Desa Wonotoro ini melewati seluruh aspek hidup sesuai tatanan struktur yang telah ada di masyarakat. Mereka melewati seluruh proses AGIL: Adaption, Goal, Attainment, Integration, dan Latency dalam upaya melakoni peran-peran sosial yang beragam.

Para perempuan menjalani proses adaptasi setelah mereka menikah. Sebelum menikah, kebanyakan para perempuan menghabiskan waktunya dengan belajar di sekolah dan di rumah serta sesekali membantu orang tua bekerja di ladang, jika ia berasal dari keluarga petani. Kebiasaan membantu orang tua di ladang, membuat para perempuan yang menikah dengan petani, mudah beradaptasi dengan kehidupan barunya sebagai keluarga petani setelah menikah. Selain beradaptasi dengan kehidupan mengolah lahan pertanian setelah menikah, para perempuan juga beradaptasi dengan peran barunya sebagai ibu dan istri. Mereka yang sudah berkeluarga menjalankan multi peran sekaligus, baik sebagai ibu rumah tangga dan juga sebagai petani. Ibu rumah tangga dalam keluarga berfungsi sebagai aktor yang mengurus segala urusan rumah tangga, dan juga berperan sebagai petani yang berfungsi sebagai pencari nafkah.

Goal atau pencapaian tujuan hidup para perempuan pun berubah setelah menikah. Pada saat sebelum menikah, para perempuan bekerja untuk tujuan membantu orangtua, sedangkan setelah menikah ia bekerja sebagai petani untuk tujuan memenuhi kewajibannya sebagai istri dan ibu.
Proses integrasi merujuk pada upaya pe rempuan mengatur hubungan di antara komponen-komponen sosial. Perempuan mematuhi nilai dan norma di masyarakat. Mereka beranggapan bahwa perempuan yang tidak bekerja dan hanya bermalas-malasan di rumah adalah suatu hal yang tabu. Anggapan yang demikian kemudian memunculkan sebuah pola terstruktur yang disebut latency atau pemeliharaan pola-pola yang sudah ada. Norma yang berkembang di masyarakat berfungsi dalam mempertahankan, memperbaiki, dan membaharui motivasi individu-individu maupun pola-pola budaya yang menciptakan dan mempertahankan motivasi-motivasi tersebut.

Berdasarkan hasil analisis Harvard, perempuan membagi waktunya dan peran dalam 24 jam dengan seksama. Sebelum menjadi pekerja di ladang, ia menjalankan peran sebagai ibu rumah tangga terlebih dahulu. Apabila pekerjaan rumah tangga telah selesai, barulah ia akan melakoni perannya sebagai pekerja di ladang.

Petani perempuan yang telah menikah tidak meninggalkan tanggung jawabnya sebagai ibu rumah tangga. Para perempuan sangat terampil membimbing anak-anaknya. Mereka mempercayai pepatah "apa yang kau tanam itu yang kau tuai" sehingga mereka juga berpikir jika anak ditinggalkan karena sibuk bekerja, maka di kemudian hari, anaknya akan sibuk bekerja dan melupakan orangtuanya.

Para perempuan juga berupaya memenuhi tugas memberikan afeksi (kasih sayang), menanamkan nilai-nilai, melakukan sosialisasi, dan memberikan pendidikan terhadap anaknya agar anak senantiasa tumbuh sesuai dengan didikan orang tua. Di dalam hal pewarisan lahan, para perempuan cenderung menyerahkan keputusan kepada anaknya. Mereka pun tidak memaksa anaknya untuk menjadi petani mengikuti pekerjaan orang tuanya.

Kerja sama antara suami dan istri (laki-laki dan perempuan) seringkali dilakukan dalam keluarga petani. Mayoritas keluarga petani memiliki dua sumber mata pencaharian, yaitu sebagai pengantar tamu dan petani. Apabila 
suami sedang menerima panggilan sebagai pengantar tamu, maka tugas dan tanggung jawab ladang diserahkan pada istrinya sampai pekerjaan pengantar tamu tersebut selesai dilakukan.

Serupa dengan teori Strukturalisme-Fungsionalisme AGIL Talcott Parson, isu multi peran gender ini menarik untuk dikaji lebih dalam menggunakan Model Analisis Gender Harvard dan Model Analisis Gender Moser. Analisis gender dibutuhkan untuk menganalisis kesenjangan gender, dengan analisis ini diharapkan mampu menginterpretasi kesenjangan gender pada konsep multi peran petani perempuan di desa ini.

Pada hasil analisis Harvard dan Moser di atas, tampak pola aktivitas selama 24 jam pada keluarga petani menunjukkan bahwa peran produktif lebih banyak dilakukan oleh perempuan. Petani perempuan menghabiskan waktu untuk melakukan peran produktif selama kurang lebih 13 jam di ladang. Selama di ladang, para petani perempuan saling memahami peran sebagai rekan kerja dan memiliki kedekatan sosial. Perempuan petani menggunakan waktu bekerja di ladang untuk menjalin ikatan sosial di antara mereka, sebab mereka akan kembali disibukkan dengan kegiatan reproduktif mereka ketika sampai di rumah. Selain di ladang, mereka hanya dapat bercengkerama dan menghabiskan waktu bersama dalam waktu yang cukup lama di hari-hari besar saja seperti dalam upacara-upacara adat.

Di keluarga petani, para suami rata-rata memiliki pekerjaan ganda, yaitu sebagai petani dan juga sebagai pengantar tamu. Perbedaan jenis kerja sama yang mereka lakukan, misalnya apabila suami-istri tersebut sama-sama merupakan petani, maka pembagian tugas yang ada pun terkait dengan ladang, biasanya anak akan dititipkan pada sanak keluarga. Hal ini berbeda apabila suami-istri mempunyai pekerjaan yang satu sama lain berbeda, yaitu sebagai pengantar tamu, maka kerja sama yang mereka lakukan adalah semata-mata untuk mendapatkan pendapatan keluarga. Lain halnya dengan petani perempuan yang telah menjadi single parent, perempuan tersebut harus mengerahkan seluruh waktu dan tenaga karena ia satu-satunya pencari nafkah di keluarga.

Pada keluarga petani di Desa Ngadisari dan Desa Wonotoro, Kecamatan Sukapura, laki-laki menduduki peran sebagai kepala keluarga, yang memiliki hak yang melekat untuk mengambil keputusan dan mengontrol urusan keluarganya, baik mengenai kebutuhan pokok maupun kebutuhan anaknya. Namun, para kepala keluarga juga memberikan hak suara pada istrinya. Laki-laki dan perempuan memiliki akses yang sama pula terhadap sumber daya fisik yang mereka miliki seperti motor trail. Petani perempuan dan laki-laki memiliki peluang yang sama untuk menggunakan aset motor tersebut untuk membantu mobilitas mereka dari satu lahan ke lahan yang lain. Pada urusan rumah tangga, perempuan memiliki hak untuk menentukan pendidikan anak-anaknya walaupun pada akhirnya keputusan akan dikembalikan kembali pada suaminya sebagai kepala keluarga mereka.

\section{Simpulan}

Penelitian ini menyimpulkan bahwa faktor-faktor yang memengaruhi peran perempuan menjadi seorang petani di Desa Ngadisari dan Desa Wonotoro, Kecamatan Sukapura, Kabupaten Probolinggo, adalah adanya sebuah tradisi masyarakat yang mewajibkan perempuan untuk menjadi mitra suaminya dalam bekerja; adanya istilah tabu bagi perempuan yang telah menikah akan tetapi tidak bekerja dan hanya berdiam diri di rumah. Hal tersebut akan menurunkan statusnya sebagai seorang istri dan ibu. Selain menjadi seorang pekerja, seorang perempuan yang telah berkeluarga tidak boleh melupakan tugasnya menjadi seorang istri bagi suaminya dan ibu bagi anaknya. Perempuan berpartisipasi dan berkontribusi pada pendapatan keluarga, tetapi tugas pemenuhan kebutuhan keluarga tetap menjadi tanggung jawab seorang perempuan, istri, dan ibu dalam keluarga. Sebagai seorang ibu, perempuan petani memiliki tugas memberikan afeksi, sosialisasi dan pendidikan pada anaknya walaupun sibuk bekerja. Pada proses 
penanaman sosialisasi dan pendidikan, anak diajarkan mampu bersosialisasi dengan keluarga dan orang lain berasaskan sopan santun. Di dalam aspek pendidikan, orang tua terutama seorang ibu harus mempedulikan perkembangan anaknya. Mereka selalu menganjurkan anaknya lulus sekolah dua belas tahun. Setelah selesai menyelesaikan pendidikan di Sekolah Menengah Atas, mereka tidak akan memaksa anaknya, karena di tahap ini anak akan diberi hak suara untuk memutuskan kehidupannya kelak.

Seluruh tahapan AGIL yaitu Adaption, Goal, Attainment, Integration, dan Latency dapat dilalui oleh perempuan di Desa Ngadisari dan Desa Wonotoro ini untuk menyeimbangkan multi peran mereka. Selain itu, mereka juga mendapat dukungan sosial yang meliputi dukungan emosional, informasional, dan konkret yang memungkinkan mereka mencegah terjadinya konflik akibat multi peran.

Analisis Gender Harvard dan Moser yang digunakan untuk analisis peran perempuan di wilayah penelitian, menemukan tiga jenis peran perempuan, yaitu peran produktif, peran reproduktif, dan peran sosial masyarakat. Perempuan membagi waktu 24 jam yang dimiliki untuk dapat menyeimbangkan kewajiban dan tanggung jawabnya. Di antara ketiga peran yang dimiliki perempuan, peran sosial masyarakat cenderung memiliki waktu yang sedikit.

\section{Daftar Pustaka}

Akbar, D. (2017). Konflik Peran Ganda Karyawan Wanita dan Stres Kerja. An-Nisa'a, 12(1), 33-48.

Anggriana, T., Margawati, T., dan Wardani, S. (2016). Konflik Peran Ganda pada Dosen Perempuan Ditinjau dari Dukungan Sosial Keluarga. Counsellia: Jurnal Bimbingan Dan Konseling, 5(1).

Apollo, dan Cahyadi, A. (2013). Konflik Peran Ganda Perempuan Menikah yang Bekerja Ditinjau dari Dukungan Sosial Keluarga dan Penyesuaian Diri. Widya Warta, 36(2), 254-271.

Creswell, J. (2013). Qualitative Inquiry and Research Design: Choosing Among Five Approaches (3rd ed.). Los Angeles: SAGE Publications Inc.
Dewi, O. K., dan Lestari, P. (2017). Peran Ganda Perempuan Buruh Tani di Desa Bojong, Kecamatan Mungkid, Kabupaten Magelang. E-Societas, 6(5).

Hartono, C., Marsito, Asti, dan Arnika, D. (2009). Hubungan antara Dukungan Sosial Keluarga dengan Tingkat Kecemasan Pasien Rawat Inap di RSU PKU Muhammadiyah Gombong. Jurnal Ilmiah Kesehatan Keperawatan, 5(1), 34-42.

Indriani, D., dan Sugiasih, I. (2018). Dukungan Sosial dan Konflik Peran Ganda terhadap Kesejahteraan Psikologis Karyawati PT. SC Enterprises Semarang. Proyeksi: Jurnal Psikologi, 11(1), 46-54.

Kusumawati, Y. (2012). Peran Ganda Perempuan Pemetik Teh. Komunitas, 4(2), 157-167.

Pramana, A. K., dan Wilani, N. (2018). Hubungan Dukungan Sosial dengan Motivasi Belajar Siswa di SMA Negeri Bali Mandara. Jurnal Psikologi Udayana, 5(1), 189-196.

Puspitawati, H. (2013). Konsep, Teori, dan Analisis Gender. Bogor.

Rahayuningsih, I. (2013). Konflik Peran Ganda pada Tenaga Kerja Perempuan. Jurnal Psikosains, 5(1), 73-86.

Rahmaharyati, A., Wibhawa, B., dan Nurwati, N. (2017). Peran Ganda Buruh Perempuan Sektor Industri dalam Keluarga. Prosiding Penelitian Dan Pengabdian Kepada Masyarakat, 230-234.

Ramadhani, N. (2016). Implikasi Peran Gnada Perempuan dalam Kehidupan Keluarga dan Lingkungan Masyarakat. Sosietas, 6(2).

Silalahi, K., dan Eko, A. (2010). Keluarga Indonesia: Aspek dan Dinamika Zaman. Jakarta: Raja Graindo Persada.

Sukesi, K. (1991). Status dan Peranan Perempuan: Apa Implikasinya bagi Studi Perempuan. Dalam Warta Studi Perempuan. Jakarta: PDII-LIPI.

Triana, A., dan Kristiani, H. (2018). Peran Ganda Ibu Rumah Tangga Pekerja K3L Unpad dalam Rangka Menunjang Perekonomian Keluarga. Prosiding Penelitian Dan Pengabdian Kepada Masyarakat, 188-197. Sumedang: Universitas Padjadjaran.

Warmiyati, M. T., Wijayanti, S. H., dan Darmoyo, S. (2018). Pemahaman tentang Sosialisasi Gender pada Siswa SMA di Jakarta. Jurnal Muara Ilmu Sosial, Humaniora, Dan Seni, 2(1), 411-419.

Wibowo, D. E. (2011). Peran Ganda Perempuan dan Kesetaraan Gender. Muwazah Jurnal 
Kajian Gender, 3(1), 356-364.

Wirawan, I. (2012). Teori-Teori Sosial dalam Tiga

Paradigma: Fakta Sosial, Definisi Sosial. Jakarta: Predamedia Group. 